\title{
INDONESIAN NANOCLAYS FOR THE REMOVAL OF NITRATE IN LIQUID WASTE CONTAINING PALM OIL MILL EFFLUENT
}

\author{
Untung Sudadi $^{1) *}$, Syaiful Anwar ${ }^{1)}$, Rendy Anggriawan ${ }^{2)}$, Tengku Afrizal ${ }^{3)}$ \\ ${ }^{1)}$ Department of Soil Science and Land Resource, Faculty of Agriculture, IPB University \\ Jl. Meranti, Campus IPB Dramaga, Bogor 16680, Indonesia \\ ${ }^{2)}$ Department of Agrotechnology, Faculty of Agriculture, Muhammadiyah University of Jember \\ Jl. Karimata 49, Jember 68121, Indonesia \\ ${ }^{3)}$ Alumni of Land Resource Management Study Program, Department of Soil Science and Land \\ Resource, Faculty of Agriculture, IPB University \\ Jl. Meranti, Campus IPB Dramaga, Bogor 16680, Indonesia \\ *Corresponding author: untungsudadi@yahoo.com
}

\begin{abstract}
Land application of liquid waste containing palm oil mill effluent (LW-POME) as soil ameliorant can cause water contamination due to its high content of nitrate if improperly treated. Indonesia is rich with volcanic tuff materials that contain variable charged soil clay minerals. This study was aimed at to extract nanoclays (fraction sized $<200 \mathrm{~nm}$ ) from volcanic tuffs of Mt. Salak, West Java, Indonesia, and evaluate their potential use as adsorbent of nitrate in LW-POME. By applying dispersion, ultrasonication, centrifugation, and dialysis separation techniques, it could be extracted positively charged nanoclays $\mathrm{nc}_{3}$ and $\mathrm{nc}_{4}$ from the respectively tuff materials $\mathrm{tv}_{3}$ and $\mathrm{tv}_{4}$. Their potential use as natural adsorbent of nitrate as anionic contaminant was evaluated using Langmuir isothermal adsorption model. After $48 \mathrm{~h}$ equilibration, it could be extracted $4.33 \mathrm{mg} \mathrm{nc} / 3 \mathrm{~g}$ $\mathrm{tv}_{3}$ and $7.73 \mathrm{mg} \mathrm{nc} / \mathrm{g} \mathrm{tv}_{4}$ with nitrate adsorption maxima of 48.3 and $40 \mathrm{mg} / \mathrm{g}$ for $\mathrm{nc}_{3}$ and $\mathrm{nc}_{4}$, respectively. The removal of nitrate in the LW-POME from 62 to $20 \mathrm{mg} / \mathrm{L}$ as to comply with the Indonesian liquid waste quality standard required $29.81 \mathrm{mg} \mathrm{nc}_{3} / \mathrm{L}$ or $39.34 \mathrm{mg} \mathrm{nc} / / \mathrm{L}$. The extracted nanoclays were considered prospective to be utilized as natural adsorbent for nitrate removal in LWPOME.
\end{abstract}

Keywords: anionic contaminant, natural adsorbent, nitrate adsorption, volcanic tuff

\section{INTRODUCTION}

Palm oil mill-effluent (POME) is a byproduct of the final production of crude palm oil and kernel palm oil processes from fresh fruit bunches in the mill. It is mainly generated from the processes of sterilization, hydro-cyclone, and clarification as condensate, drain-off, and sludge, respectively (Igwe and Onyegbado, 2007; Wu et al., 2010). After treated in ponding systems, it is commonly recycled by oil palm plantation companies in Indonesia and Malaysia as soil ameliorant by way of land application practice (Amelia et al., 2017; Kamyab et al., 2018). However, application of this practice for long-term period can generate negative environmental impacts, one of which is nitrate contamination in waters of the surrounding plantation area.

Soils and soil parent materials are potential source of natural adsorbent for the removal of anionic contaminants such as phosphate, fluorate, and arsenate in waters, wastewater, and liquid waste (Gitari and Mudzielwan, 2015; Sudadi et al., 2019; Wambu et al., 2015). From volcanic tuff materials, that are abundant in Indonesia, it can be extracted fraction with physical dimension of $<200 \mathrm{~nm}$ (Kaufold et al., 2010; Shukla et al., 2013; Sudadi et al., 2019). These nanoclays pose a pH-dependent charge characteristic (Kaufold et al., 2010). Being treated or modified in acid condition, the nanoclays perform positive charge characteristic and 
hence can be utilized as natural adsorbent for the removal of anionic contaminants (Shukla et al., 2013).

This study was aimed at to extract nanoclays from volcanic tuff materials of Mt. Salak, Indonesia, and to evaluate their potential use as natural adsorbent for the removal of nitrate in liquid waste containing palm oil mill effluent. Subsequently in this paper, the latter is abreviated as LW-POME.

\section{METHOD}

\section{Tools and Materials}

The tools used in this study consist of glasswares, 240-mesh sieve, digital analytical balance, oven, ultrasonic, centrifuge, pH-meter, spray bottle, ECmeter, Kjeldahl apparatus, and UV-Vis spectrophotometer. For data analysis, we applied Microsoft Office Excell and SAS statistical softwares.

The tuff materials used in this study $\left(\operatorname{tv}_{3}\right.$ and $\left.\mathrm{tv}_{4}\right)$ were collected from the $3^{\text {rd }}$ $(87-135 \mathrm{~cm}$ depth $)$ and $4^{\text {th }}(>135 \mathrm{~cm}$ depth) layers of an Andisol profile at the slope (670 m asl) of Mt. Salak located in Sukajadi Village, Tamansari Subdistrict, Bogor Regency, West Java (6 $6^{\circ} 39^{\prime} 28^{\prime}$ ' S and $106^{\circ} 43^{\prime}$ 52.2' ' E) in March 2017. The sample of LW-POME was collected from a palm oil plantation mill in Rokan Hulu Regency, Riau in July 2017. The experiment was conducted in March to July 2017 at the Soil Chemistry and Fertility Laboratory, Department of Soil Science and Land Resource, Faculty of Agriculture, IPB University.

\section{Extraction of Nanoclay Fraction}

Briefly, by dispersing in acid condition, followed with ultrasonication, centrifugation, and purification using membrane dialysis technique, it can be extracted nanoclay fraction from volcanic tuff materials. This procedure refers to Henmi and Wada (1976) that was modified by Calabi-Floody et al. (2009;
2011) with the addition of ultrasonication step.

Detail of the procedure is described as follows. Water content of the air dried 240 mesh sieved-tuff materials ( $\mathrm{tv}_{3}$ and $\mathrm{tv}_{4}$ ) were first determined using gravimetric procedure. Initial chemical analysis of $\mathrm{tv}_{3}$ and $\mathrm{tv}_{4}$ was conducted for $\mathrm{pH} \mathrm{H}_{2} \mathrm{O}$, $\mathrm{pH} \mathrm{NaF}$, and organic-C content. Then, 10 $\mathrm{g}$ of $\mathrm{tv}_{3}$ and $\mathrm{tv}_{4}$ were separately put into 2 cylinders-1L, added each with aquadest up to $1 \mathrm{~L}$ total volume, conditioned into $\mathrm{pH}$ 4.0 by addition of $4.5 \mathrm{~mL} 0.21 \mathrm{~N} \mathrm{HCl}$, ultrasonicated at sonic wave of $20 \mathrm{kHz}$ for $15 \mathrm{~min}$, and sedimented for $20 \mathrm{~h}$. Afterwards, the top $10 \mathrm{~cm}$ solutions (around $200 \mathrm{~mL}$ each), which were considered to contain nanoclay fractions with positive charge characteristic, were transferred using plastic pipe into beaker glass- 1000 $\mathrm{mL}$. This step was conducted 8 times, using in total $84.41 \mathrm{~g}$ air-dried $\mathrm{tv}_{3}$ and tv 4 each, until around $1600 \mathrm{~mL}$ of the top 10 $\mathrm{cm}$ solutions each were obtained. The solutions were then flocculated using 100 $\mathrm{mL} N \mathrm{NaCl}$ and resedimented for another $20 \mathrm{~h}$. The top clear solutions were then decanted and the flocculated fractions of around $160 \mathrm{~mL}$ each were kept for the next steps.

The $160 \mathrm{~mL}$ flocculated fractions of $\mathrm{tv}_{3}$ and $\mathrm{tv}_{4}$ from the previous step were redispersed at $\mathrm{pH} 4.0$ and then transferred each separately into 4 centrifuge bottles- 40 $\mathrm{mL}$. The volume or height of the solutions in all bottles were made equal by addition of aquadest in order to obtain optimal centrifugations at $3500 \mathrm{rpm}$ for 4 x $30 \mathrm{~min}$. After the fourth centrifugation, it can be differentiated of about $1 \mathrm{~cm}$ top clear solution part, which was considered as the excess $\mathrm{NaCl}$ from the flocculation step, with the suspension and solid parts below it. The top clear solution part was decanted, whilst the suspension and solid parts, which were considered as to contain the extracted nanoclay fraction, were transferred into beaker glass-500 mL. 
The suspension was directly transferred into the other beaker glass, while the solids were dissolved first with aquadest by mean of spray bottle. Then, the accumulated suspensions in beaker glass were further purified from the excess $\mathrm{NaCl}$ by performing membrane-dialysis technique.

At the dialysis step, an amount of nanoclay suspension was put into dialysis membrane of about $4 \mathrm{~cm}$ length and tied at both ends at about $1 \mathrm{~cm}$ position using strings and then soaked with drift position in beaker glass containing $1000 \mathrm{~mL}$ aquadest. During this step, aquadest in the beaker glass was changed regularly with the fresh one until an equilibrium condition was attained, inwhich the concentration of ions inside the membrane was equal to those in aquadest outside the membrane or when the electrical conductivity (EC) of aquadest in the beaker glass was almost equal to that of pure aquadest $(0.5-0.8 \mu \mathrm{S} / \mathrm{cm})$, indicating that nanoclay suspension inside the membrane was already free from the excess $\mathrm{NaCl}$ and therefore assumed to contain only positively charged reactivenanoclays. The EC determination were done using EC-meter.

The next step was determination of the extracted nanoclay concentration in the suspension. Each suspension, i.e. originated from $\mathrm{tv}_{3}$ and $\mathrm{tv}_{4}$, was transferred from the corresponding membranes into 2 volumetric flasks-500 mL separately and made up the volume by addition of aquadest. Up to this step, nanoclay $\mathrm{nc}_{3}$ and $\mathrm{nc}_{4}$ originated respectively from $\mathrm{tv}_{3}$ and $\mathrm{tv}_{4}$ materials were already obtained and ready for use for the LW-POME nitrate adsorption batch-experiment.

The concentrations of nanoclays $\mathrm{nc}_{3}$ and $\mathrm{nc}_{4}$ in each $500 \mathrm{~mL}$ suspensions in the corresponding volumetric flasks were determined gravimetrically with 3 replications by pippeting $10 \mathrm{~mL}$ of each suspension into oven plates and oven-dried at $105^{\circ} \mathrm{C}$ for $24 \mathrm{~h}$ or until their constant weighs were obtained. Then, percentage of the respectively dry weight of $\mathrm{nc}_{3}$ and $\mathrm{nc}_{4}$ per unit dry weight of $\mathrm{tv}_{3}$ and $\mathrm{tv}_{4}$ were calculated.

\section{Nitrate Adsorption Test}

Briefly, nitrate adsorption test was carried out by referring to the Langmuir isothermal adsorption model. The test was performed by conducting batch experiment to obtain adsorption maxima (b value) of LW-POME nitrate onto the extracted nanoclays at 4 equilibration times, i.e. 12 , 24,48 , and $72 \mathrm{~h}$, each with 3 replications.

The batch experiments consisted of $2 \times 4$ sets of 6 polyetilene tubes. Twenty four tubes were contained with $0,2.5,5$, 10,15 , dan $20 \mathrm{~mL}$ suspension containing nanoclay $\mathrm{nc}_{3}$ and the other 24 tubes with those of $\mathrm{nc}_{4}$, respectively, added each with $20 \mathrm{~mL} \mathrm{LW-POME,} 5 \mathrm{~mL} 0.01 \mathrm{~N} \mathrm{CaCl}_{2}$ as background electrolyte, and aquadest up to a total volume of $50 \mathrm{~mL}$. Then, the tubes were equilibrated for $12,24,48$, or $72 \mathrm{~h}$ by way of agitation for $30 \mathrm{~min}$ using mechanical end-to-end shaker at time 0,6 , and $12 \mathrm{~h}$ for the first set; at time $0,6,12$, 18 , and $24 \mathrm{~h}$ for the second set; at time 0 , $6,12,18,24,30,36,42$, and $48 \mathrm{~h}$ for the third set, and at time $0,6,12,18,24,30$, $36,42,48$, and $72 \mathrm{~h}$ for the fourth set. After these equilibrations, the suspensions were centrifugated and filtered for the determination of nitrate concentration in the aliquot using Kjeldahl method.

The general Langmuir isothermal adsorption model, $\mathrm{x} / \mathrm{m}=\mathrm{kbC} / 1+\mathrm{kC}$, can be converted into a linear equation $\mathrm{C} / \mathrm{x} / \mathrm{m}$ $=1 / \mathrm{b}+1 / \mathrm{kb} \mathrm{C}$, where $\mathrm{x} / \mathrm{m}$ stands for the amount of nitrate adsorbed per unit weight of nanoclay $(\mathrm{mg} / \mathrm{g})$, i.e. the difference between the added nitrate concentration (20 mL LW-POME containing $62 \mathrm{mg}$ nitrate/ $\mathrm{L}$ added into the $50 \mathrm{~mL}$ solution series containing nanoclay suspensions from 0 to $20 \mathrm{~mL}$ ) and nitrate concentration at equilibrium state $(\mathrm{C}, \mathrm{mg} / \mathrm{L})$. The data obtained were then simulated using the linear Langmuir equation to obtain $b$ 
values (adsorption maxima, $\mathrm{mg} / \mathrm{g}$ ). The $\mathrm{b}$ value was calculated based on the intercept of the curve $(1 / \mathrm{b}$ value of the resulted linear regression equation $\mathrm{C} / \mathrm{x} / \mathrm{m}=1 / \mathrm{b}+$ $1 / \mathrm{kb} \mathrm{C})$.

\section{Data Analysis}

The linear Langmuir equations were determined using Microsoft Excell software. Statistical analysis to determine mean difference significance amongst the adsorption maximas (b values) of nitrate contained in LW-POME into the nanoclays $\mathrm{nc}_{3}$ and $\mathrm{nc}_{4}$ at $12,24,48$, and 72 $\mathrm{h}$ equilibration times were performed by applying t-test using SAS software.

\section{RESULTS AND DISCUSSION}

\section{Extracted Nanoclays}

Volcanic tuff material is a pyroclactic substance originated from volcano eruption that is already solidified and lithified due to association with water. Andisols in the sampling location of volcanic tuffs used in this study were developed from andesitic volcanic parent materials of Mt. Salak (Van Ranst et al., 2002). Weathering results of the acidic volcanic tuff material forms, among others, nanoclay fraction which contains nanocrystaline aluminosilicate minerals nanoball allophane (diameter of 3.5-5 nm) and nanotube imogolite (diameter of 1-3 $\mathrm{nm})$ that poses $\mathrm{pH}$-dependent charge characteristic (Abidin et al., 2007). In acid condition, it behaves positive charge, while in alkaline condition it behaves negative charge. The positive charge is originated from protonation of hydroxil groups at the silanol (Si-OH), aluminol $(\mathrm{Al}-\mathrm{OH})$, and ferol $(\mathrm{Fe}-\mathrm{OH})$ reactive surfaces so that anion can be adsorbed. Whilst the negative charge is originated from deprotonation of hydroxil groups at the same reactive surfaces so that cation can be attracted (Abidin et al., 2007; Calabi-floody et al., 2009, 2011; Tan, 1998).
Table 1 shows that the volcanic tuff materials $\mathrm{tv}_{3}$ were characterized with lower $\mathrm{pH} \mathrm{H}_{2} \mathrm{O}$ and $\mathrm{pH} \mathrm{NaF}$ but higher organic-C content than those of $\mathrm{tv}_{4}$. As to contain aluminosilicate minerals, nanoclay fractions poses $\mathrm{OH}^{-}$terminals at each of its silanol ( $\mathrm{Si}-\mathrm{OH})$, aluminol $(\mathrm{Al}-\mathrm{OH})$, and ferol $(\mathrm{Fe}-\mathrm{OH})$ reactive surfaces. In the course of $\mathrm{pH} \mathrm{NaF}$ determination, ion $\mathrm{F}^{-}$ from $\mathrm{NaF}$ replaced hydroxide ion $\left(\mathrm{OH}^{-}\right)$at those reactive surfaces and released it to the soil solution so that increased the $\mathrm{pH}$ value. Hence, the higher the $\mathrm{pH} \mathrm{NaF}$ value of the solution obtained, the higher the concentration of the extracted nanoclays could be expected (Tan, 1998). As shown in Table 2, from $84.42 \mathrm{~g} \mathrm{tv}_{3}$ it could be extracted $0.28 \mathrm{~g}$ nanoclay fraction $\mathrm{nc}_{3}$ that equals to $4.33 \mathrm{mg} \mathrm{nc}_{3} / \mathrm{g} \mathrm{tv}_{3}$, whilst from $84.42 \mathrm{~g} \mathrm{tv}_{4}$ it could be extracted 0.48 g nanoclay fraction $\mathrm{nc}_{4}$ that equals to 7.73 $\mathrm{mg} \mathrm{nc}_{4} / \mathrm{g} \mathrm{tv}_{4}$, Concentration of the nanoclays that could be extracted from tv 4 was higher than that of $\mathrm{tv}_{3}$ which was in accordance with the higher $\mathrm{pH} \mathrm{NaF}$ of $\mathrm{tv}_{4}$ than that of $t_{3}$. Furthermore, the higher organic-C content in $\mathrm{tv}_{3}$ made it more difficult to extract nanoclay fraction from $\mathrm{tv}_{3}$ as compared to $\mathrm{tv}_{4}$ because of the aggregation effect of organic matter (Tan, 1998).

\section{Nitrate Adsorption Characteristic of Extracted Nanoclays}

Table 2 shows that the nitrate adsorption maxima (b value) of $\mathrm{nc}_{3}$ were higher than those of $\mathrm{nc}_{4}$ at all of the four equilibration time tested $(12,24,48$, and $72 \mathrm{~h}$ ). Therefore, $\mathrm{nc}_{3}$ was considered more prospective than $\mathrm{nc}_{4}$ to be utilized as adsorbent for the removal of anionic contaminant such as nitrate contained in the tested LW-POME.

The $b$ value or adsorption maxima of an adsorbent is, among others, affected by its particle size. Therefore, results of this study indicated that there was a difference in particle size between $\mathrm{nc}_{3}$ and $\mathrm{nc}_{4}$. This is probably due to the difference in 
crystallization state. Position of $\mathrm{tv}_{3}$ layer in the soil profile was closer to the parent material than that of $\mathrm{tv}_{4}$. The closer the layer position to the parent material, the lower the weathering and crystallization level of the formed minerals (Tan, 1998).

\section{Effects of Equilibration Time}

Results of the t-test (Table 3) show that nitrate adsorption maxima of the extracted nanoclay $\mathrm{nc}_{3}$ and $\mathrm{nc}_{4}$ after equilibrated for $12 \mathrm{~h}$ were not significantly different with those of $24 \mathrm{~h}$, whilst those of $48 \mathrm{~h}$ were significantly higher than those of 24 for both and of $72 \mathrm{~h}$ for $\mathrm{nc}_{4}$. This indicated that increasing equilibration up to $72 \mathrm{~h}$ did not result in higher nitrate adsorption significantly. Therefore, the most effective equilibration for application of the extracted nanoclays as adsorbent of nitrate was $48 \mathrm{~h}$. Using the same extracted nanoclays that were tested to adsorp phosphate in a eutrophic water, the most effective equilibration time obtained was also $48 \mathrm{~h}$ as to compared to those of 12 and $24 \mathrm{~h}$ (Sudadi et al., 2019).

\section{Nanoclays Required to Reduce Nitrate as to Comply with the Wastewater Quality Standard}

For the intention to utilize the extracted nanoclays as adsorbent of nitrate in the management of liquid waste or contaminated waters, then it is necesary to calculate the required amount of the nanoclays to reduce the contamination level as to comply with the liquid waste quality standard that apply. The quality

Table 1. Properties of the volcanic tuff materials of Mt. Salak, West Java, Indonesia

\begin{tabular}{ccccc}
\hline Sample Code & $\begin{array}{c}\text { Depth of } \\
\text { sampling } \\
(\mathrm{cm})\end{array}$ & $\begin{array}{c}\mathrm{pH} \mathrm{H}_{2} \mathrm{O} \\
1: 5\end{array}$ & $\begin{array}{c}\mathrm{pH} \mathrm{NaF} \\
1: 5\end{array}$ & $\begin{array}{c}\text { Organic-C } \\
(\%)\end{array}$ \\
\hline $\mathrm{tv}_{3}$ & $87-135$ & 5.13 & 11.08 & 0.99 \\
$\mathrm{tv}_{4}$ & $135+$ & 5.58 & 11.35 & 0.09 \\
\hline
\end{tabular}

Table 2. Extracted nanoclays from the volcanic tuff materials of Mt. Salak, West Java, Indonesia

\begin{tabular}{|c|c|c|c|c|c|c|}
\hline \multicolumn{4}{|c|}{ Volcanic tuff material } & & \multirow{2}{*}{\multicolumn{2}{|c|}{$\frac{\text { Extracted manoclays }}{\text { Dry weight }}$}} \\
\hline & $\begin{array}{l}\text { Air dry } \\
\text { weight }\end{array}$ & $\begin{array}{l}\text { Water } \\
\text { content }\end{array}$ & Dry weight & & & \\
\hline & $\mathrm{g}$ & $\%$ & $\mathrm{~g}$ & & $\mathrm{mg}$ & $\mathrm{mg} / \mathrm{g} \mathrm{tv}$ \\
\hline $\mathrm{tv}_{3}$ & 84.42 & 30.80 & 64.53 & $\mathrm{nc}_{3}$ & 0.28 & 4.33 \\
\hline $\mathrm{tv}_{4}$ & 84.42 & 37.36 & 61.45 & $\mathrm{nc}_{4}$ & 0.48 & 7.73 \\
\hline
\end{tabular}

Table 3. Nitrate adsorption maxima of the extracted nanoclays from volcanic tuff materials of Mt. Salak, West Java, Indonesia

\begin{tabular}{ccccc}
\hline & \multicolumn{5}{c}{ Average value of nitrate adsorption maxima } \\
\hline & \multicolumn{4}{c}{ Equilibration time } \\
\cline { 2 - 5 } Extracted & $12 \mathrm{~h}$ & $24 \mathrm{~h}$ & $48 \mathrm{~h}$ & $72 \mathrm{~h}$ \\
\cline { 2 - 5 } nanoclays & \multicolumn{4}{c}{$\mathrm{mg} / \mathrm{g}$} \\
\hline $\mathrm{nc}_{3}$ & $25.06 a$ & $32.25 a b c$ & $48.30 d$ & $26.59 a b$ \\
$\mathrm{nc}_{4}$ & $21.40 q$ & $25.97 q r$ & $40.00 \mathrm{~s}$ & $10.68 p$ \\
\hline
\end{tabular}

Note: "Means in the same row with different italic letter differ significantly $(p<0.05)$ " 
standard of nitrate concentration in liquid waste or effluent of oil palm mill of category I according to the Ministry of Environment Regulation, Republic of Indonesia No.5 year 2014 is $20 \mathrm{mg}$ nitrate/L.

Weight of the extracted nanoclays required to reduce nitrate concentration in the LW-POME to $20 \mathrm{mg}$ nitrate/L was determined by means of linear regression analysis of the relationship between the applied weight of nanoclay (mg) as X-axis and the resulted nitrate concentration $(\mathrm{mg} / \mathrm{L})$ after $48 \mathrm{~h}$ equilibration as $\mathrm{Y}$-axis. Then, the obtained $\mathrm{X}$ value perpendicular to the intersection point of the regresion curves $\left(\mathrm{Y}_{\mathrm{nc} 3}=-1.25 \mathrm{X}+57.27(\mathrm{r}=0.983\right.$, $p<0.01$ and $\mathrm{Y}_{\mathrm{nc} 4}=-0.908 \mathrm{X}+55.73(\mathrm{r}=$ $0.977, p<0.01)$ with the horizontal line at $\mathrm{Y}=20 \mathrm{mg}$ nitrate/L showed the required weight of the extracted nanoclays for the purpose.

The required weight of $\mathrm{nc}_{3}(29.81$ $\mathrm{mg} / \mathrm{L}$ ) for the purpose to reduce nitrate concentration in the LW-POME from 62 to $20 \mathrm{mg} / \mathrm{L}$ was lower than that of $\mathrm{nc}_{4}$ (39.34 $\mathrm{mg} / \mathrm{L})$. This was related to the higher value of adsorption maxima of $\mathrm{nc}_{3}$ than that of $\mathrm{nc}_{4}$ (Table 3). However, the extracted amount of $\mathrm{nc}_{3}$ per unit weight of the corresponding tuff material was lower than that of $\mathrm{nc}_{4}$ (Table 2). Consequently, to obtain an equal application efficacy of the extracted nanoclays as adsorbent of nitrate, the required amount of $\mathrm{tv}_{3}$ would be higher than that of $\mathrm{tv}_{4}$ or vice-versa. Similar result was obtained from application of the same nanoclays as adsorbent of phosphate in eutrophic water (Sudadi et al., 2019).

\section{CONCLUSION}

After $48 \mathrm{~h}$ equilibration, it could be extracted $4.33 \mathrm{mg} \mathrm{nc}_{3} / \mathrm{g} \mathrm{tv}_{3}$ and $7.73 \mathrm{mg}$ $\mathrm{nc}_{4} / \mathrm{g}$ tv 4 . The nitrate adsorption maxima of $\mathrm{nc}_{3}$ was higher than that of $\mathrm{nc}_{4}$. The removal of nitrate in the LW-POME from $62 \mathrm{mg} / \mathrm{L}$ to $20 \mathrm{mg} / \mathrm{L}$ as to comply with the quality standard of nitrate concentration in liquid waste of oil palm mill of category I according to the Ministry of Environment Regulation No.5/2014 required $29.81 \mathrm{mg}$ $\mathrm{nc}_{3} / \mathrm{L}$ or $39.34 \mathrm{mg} \mathrm{nc} / \mathrm{L}$. The extracted nanoclays were prospective to be utilized as adsorbent for nitrate removal in LWPOME.

\section{REFERENCES}

Abidin, Z., Matsue, N., Henmi, T. 2007. Differential formation of allophane and imogolite: Experimental and molecular orbital study. J. Computer-Aided Mater Des., 14: 5-8.

Amelia, J.R., Suprihatin, S., Indrasti, N.S., Hasanudin, U., Murakami, R., Fujie, K. 2017. Effects of treated palm oil mill effluent application on the soil microbial community structure and oil palm plantation productivity. J. Water Environ. Tech., 15 (3): 77-85.

Calabi-Floody, M., Theng, B.K.G., Preyes, P., Mora, M.L. 2009. Natural nanoclays: Applications and future trends - a Chilean perspective. Clay Mine.r, 44: 161-176.

Calabi-Floody, M., Bendall, J.S., Jara, A.A., Welland, M.E., Theng, B.K.G., Rumpel, C., Mora, M.L. 2011. Nanoclays from an Andisol: Extraction, properties and carbon stabilization. Geoderma, 161: 159-167.

Gitari, M.W., Mudzielwana, R. 2018. Mineralogical and chemical characteristics of raw and modified clays and their application in arsenic and fluoride removal: Review, current topics in the utilization of clay in industrial and medical applications. Mansoor Zoveidavianpoor, IntechOpen. [DOI: 10.5772/ intechopen.74474].

Henmi, T., Wada, K. 1976. Morphology and composition of allophane. Amer. Mineralogist, 61: 379 -390.

Igwe, J.C., Onyegbado, C.C. 2007. A review of palm oil mill effluent (Pome) water treatment. Global J. Environ. Res., 1 (2): 54-62. 
Kamyab, H., Chelliapan, S., Md Din, M.F., Rezania, S., Khademi, T., Kumar, A. 2018. Palm oil mill effluent as an environmental pollutant, Palm Oil, Viduranga Waisundara, IntechOpen, [DOI: 10.5772/intechopen.75811].

Kaufold, S.D., Abidin, Z., Henmi, T., Matsue, N., Eichinger, L., Kaufold, A., Jahn, R. 2010. Allophane compared with other sorbent minerals for the removal of fluoride from water with particular focus on a mineable Ecuadorian allophane. Appl. Clay Sci., 50: 25-33.

Ministry of Environment Regulation. 2014. Republic of Indonesia Number 05 year 2014 Concerning the Quality Standards of Wastewaters. 85 p. (in Indonesian).

Shukla, E.A., Johan, E., Abidin, Z.A., Henmi, T., Matsue, N. 2013. A comparative study of arsenate and phosphate adsorption on nano-ball allophane. Clay Sci., 17: 83-91.

Sudadi, U., Anggriawan, R., Anwar, S. 2019. Application of nanoclays from volcanic tuff of Salak Mountain, Indonesia as a natural adsorbent of anionic contaminants: Phosphate in water environment (in Indonesian). JPSL, 9 (4): 1032-1040. [DOI:10.29244/jps1.9.4.1032-1040].
Tan, K.H. 1998. Principles of Soil Chemistry. $3^{\text {rd }}$ Ed, Revised and Expanded. Marcel Dekker Inc., New York, USA.

Van Ranst, E., Utami, S.R., Shamshuddin, J. 2002. Andisols on volcaninc ash from Java Island, Indonesia: Physicochemical properties and classification. Soil Sci., 167 (1): 68-79.

Wambu, E.W., Ambusso,W., Onindo, C.O., Muthakia, G.K. 2015. Review of fluoride removal from water by adsorption using soil adsorbents - An evaluation of the status. J. Water Reuse Desalination, 8 (1). [DOI: 10.2166/wrd. 2015.073].

Wu, T.Y., Mohammad, A.W., Md. Jahim, J., Anuar, N. 2010. Pollution control technologies for the treatment of palm oil mill effuent (POME) through end-ofpipe processes. J. Environ. Manag., 91: 1467-1490. 